\title{
Article \\ Crystal Structures of Gallium(III) Halides with Bulky Ligands
}

\author{
Manluan Sun ${ }^{1, \dagger}$, Sai Ge ${ }^{1, *,+}$, Jianguo Zhao ${ }^{1, *}$, Robert McDonald ${ }^{2}$, Michael Ferguson ${ }^{2}$ and Guibin Ma ${ }^{1,2}$ \\ 1 Institute of Carbon Materials Science, Shanxi Datong University, Datong 037009, China; \\ dtusml@sxdtdx.edu.cn (M.S.); guibin@ualberta.ca (G.M.) \\ 2 Department of Chemistry, University of Alberta, Edmonton, Alberta, AB T6G 2G2, Canada; \\ bob.mcdonald@ualberta.ca (R.M.); michael.ferguson@ualberta.ca (M.F.) \\ * Correspondence: dtugs@sxdtdx.edu.cn (S.G.); jgzhaoshi@163.com (J.Z.) \\ + These authors contributed equally to this work.
}

Citation: Sun, M.; Ge, S.; Zhao, J.; McDonald, R.; Ferguson, M.; Ma, G. Crystal Structures of Gallium(III)

Halides with Bulky Ligands. Crystals 2022, 12, 330. https://doi.org/ 10.3390 /cryst 12030330

Academic Editor: Kil Sik Min

Received: 4 February 2022

Accepted: 23 February 2022

Published: 27 February 2022

Publisher's Note: MDPI stays neutral with regard to jurisdictional claims in published maps and institutional affiliations.

Copyright: () 2022 by the authors Licensee MDPI, Basel, Switzerland. This article is an open access article distributed under the terms and conditions of the Creative Commons Attribution (CC BY) license (https:// creativecommons.org/licenses/by/ $4.0 /)$.

\begin{abstract}
Three oxygen donor gallium(III) halide complexes, $\left[\mathrm{GaX}_{3}\left(\mathrm{O}=\mathrm{P}(\mathrm{TMP})_{3}\right](\mathrm{TMP}=\right.$ trimethoxylphenyl and $\mathrm{X}=\mathrm{Cl}^{-}(\mathbf{1}), \mathrm{Br}^{-}(\mathbf{2})$ and $\left.\mathrm{I}^{-}(3)\right)$, are prepared by oxidation in mixed solvents from their phosphine adducts of $\left[\mathrm{GaX}_{3}\left(\mathrm{P}(\mathrm{TMP})_{3}\right]\right.$. Three crystalline compounds are obtained from the solutions and their crystal structures are determined in the solid state. It is rare to generate a crystalline phase for metal-adduct compounds of this bulky ligand; in this paper, three new crystal structures are presented.
\end{abstract}

Keywords: gallium; donor-acceptor complex; halides; tris( $p$-methoxylphenyl) phosphine oxide; crystal structure

\section{Introduction}

The classic donor-acceptor complex $\mathrm{H}_{3} \mathrm{~N}-\mathrm{BF}_{3}$ was first prepared in 1809 by GayLusac; it was analyzed using microwave spectroscopy in the gaseous phase by Legon and Waener and studied via quantum mechanical calculations by Frenking [1]. It is well-known that group 13 metal halides of the type $\mathrm{MX}_{3}\left(\mathrm{M}=\mathrm{B}, \mathrm{Al}, \mathrm{Ga}\right.$, In and $\mathrm{Tl}, \mathrm{X}=\mathrm{Cl}^{-}, \mathrm{Br}^{-}$, $\mathrm{I}^{-}$) have electron pair acceptor orbitals and can easily form donor-acceptor complexes with nitrogen, oxygen, sulfur and phosphine donor atoms [2]. We recently synthesized and structurally characterized two nitrogen donor atom complexes of group 13 elements with a bis(iminoophosphorano)methanide chelate ligand to form a $\left(\mathrm{C}^{-} \mathrm{P}_{2} \mathrm{~N}_{2} \mathrm{M}^{+} \mathrm{X}_{2}\right)$ sixmember ring with an intramolecular ionic charge separation interaction $[3,4]$. There are other unusual donor-acceptor types of adducts, for example thallium (Tl(III)) platinum $(\mathrm{Pt}(\mathrm{II}))$; it has been reported that the occupied $d_{\mathrm{z}}{ }^{2}$ orbital electron pairs can act as potential donor electrons to empty $\mathrm{Tl}(\mathrm{III}) s$ orbitals to form $\mathrm{Pt}(\mathrm{II})-\mathrm{Tl}(\mathrm{III})$ metal-metal bond complexes. A large spin-spin coupling constant $J\left({ }^{205} \mathrm{Tl},{ }^{195} \mathrm{Pt}\right)$ was observed from both ${ }^{205} \mathrm{Tl}$ and ${ }^{195} \mathrm{Pt}$ NMR spectroscopy, indicating the presence of a strong metal-metal donor-acceptor interaction $[5,6]$.

The coordination complexes of gallium(III) and indium(III) halides with phosphine ligands were reported by Carty as early as 1967 [7,8]. Although composition and spectroscopy data were available from these studies, crystal structures were not reported [7,8]. Previously, we undertook solid-state NMR studies of the quadrupolar nuclei of the 1:1 adducts formed by gallium(III) and indium(III) halides with triarylphosphines [9,10]. Crystal structure data for these complexes were essential to interpret the complicated solid NMR spectral data. However, at the time, we were unsuccessful in our attempts to crystalize the 1:1 adducts. The greatest challenge was that, during the synthesis process, these complexes quickly precipitated as white powders, then these powders were difficult to dissolve in any solvents.

In our previous work $[9,10]$, we used a synthesis procedure similar to that reported in the literature $[7,8]$. Typically, anhydrous gallium(III) and indium(III) halides were 
dissolved in either anhydrous ethyl acetate or toluene, then mixed with a 1:1 stoichiometric amount of phosphine in the same solvent. White powders of the complexes were obtained after filtering in a dry glove box. We realized that a small amount of the synthesized adduct remained in the mother liquid and was very stable in solution. We determined that crystal growth from the mother liquids work very well and resulted in almost complete synthesis of complex crystals from the filtered mother liquid solution in a dry glove box $[9,10]$. In addition to our solved crystal structures, there are 37 indium and gallium adduct crystal structures with triphenylphosphine and triphenylphosphine oxide ligands available from the CCDC database. Of interest to the present work are a few structures with triphenylphosphine oxide as ligands [11-16].

The gallium(III) and indium(III) halides considered in this paper and in particular the gallium(III) metal halides are very hygroscopic and easily hydrolyze in air. However, their 1:1 adducts in the solid state are relatively stable in air and do not appear to be hygroscopic. We were surprised to find that these 1:1 adducts, but especially gallium(III) halides with phosphine ligands, are unstable in solutions, not due to hydrolysis but rather due to the formation of phosphine oxide complexes in the presence of oxygen. In this paper, we present a study of the formation of oxygen donor complexes with gallium halides through the oxidation reaction of the binding methoxy-substituted triphenylphosphine (TPP) ligands.

\section{Materials and Methods}

Owing to the ease of hydrolysis of the anhydrous halides, all operations were carried out in a dry box. Anhydrous solvents were used in all preparations.

\subsection{Materials}

$\mathrm{GaCl}_{3}, \mathrm{GaBr}_{3}, \mathrm{GaI}_{3}$, tris(2,4,6-trimethoxyphenyl)phosphine (TMP), 98\%, were purchased from Strem (Newburyport, MA, USA); all chemicals were used as received.

\subsection{Synthesis of the Complexes}

A similar procedure was used for the synthesis of $\mathrm{Cl}_{3} \mathrm{Ga}(\mathrm{TMP}), \mathrm{Br}_{3} \mathrm{Ga}(\mathrm{TMP})$ and $\mathrm{I}_{3} \mathrm{Ga}(\mathrm{TMP})[7,8]$. Unless otherwise noted, reactions were carried out in ethyl acetate. Typically, equimolar gallium trihalide and the TMP ligand were dissolved in approximately $5 \mathrm{~mL}$ ethyl acetate. After $30 \mathrm{~min}$ stirring, white crystals of these complexes precipitated from the solutions, which were collected and washed with a small amount of ethyl acetate and dried in vacuo. $\mathrm{Cl}_{3} \mathrm{Ga}(\mathrm{TMP}): 0.352 \mathrm{~g} \mathrm{GaCl}_{3}(0.2 \mathrm{mmol})$ and $1.064 \mathrm{~g}$ TMP $(0.2 \mathrm{mmol})$ were used and 1.08 g product was obtained, yield $76.0 \%$. Anal. Calc. for $\left(\mathrm{C}_{27} \mathrm{H}_{33} \mathrm{Cl}_{3} \mathrm{GaO}_{9} \mathrm{P}\right)$ : C, $45.76 \%$, H, 4.69\%. Found: C, 45.42\%, H, 4.83\%. $\mathrm{Br}_{3} \mathrm{Ga}$ (TMP): $0.310 \mathrm{~g} \mathrm{GaBr}_{3}(0.1 \mathrm{mmol})$ and $0.532 \mathrm{~g}$ TMP $(0.1 \mathrm{mmol})$ were used and $0.73 \mathrm{~g}$ product was obtained, yield $87.0 \%$. Anal. Calc. for $\left(\mathrm{C}_{27} \mathrm{H}_{33} \mathrm{Br}_{3} \mathrm{GaO}_{9} \mathrm{P}\right)$ : C, $38.52 \%$, H, 3.95\%. Found: $\mathrm{C}, 38.74 \%, \mathrm{H}, 3.97 \%$. I ${ }_{3} \mathrm{Ga} \cdot(\mathrm{TMP})$ : $0.450 \mathrm{~g} \mathrm{GaI}_{3}(0.1 \mathrm{mmol})$ and $0.532 \mathrm{~g}$ TMP $(0.1 \mathrm{mmol})$ were used and $0.69 \mathrm{~g}$ product was obtained, yield $71.0 \%$. Anal. Calc. for $\left(\mathrm{C}_{27} \mathrm{H}_{33} \mathrm{I}_{3} \mathrm{GaO}_{9} \mathrm{P}\right)$ : C, 32.99\%, H, 3.38\%. Found: $\mathrm{C}$, $33.30 \%, \mathrm{H}, 3.50 \%$.

The three new oxide compounds of $\left[\mathrm{GaX}_{3}(\mathrm{O}=\mathrm{P}(\mathrm{TMOP}) 3]\right.$ ( $\mathrm{TMOP}=$ trimethoxylphenyl) were prepared through the oxidation of three TMP solid complexes of $\mathrm{Cl}_{3} \mathrm{Ga}(\mathrm{TMP})$, $\mathrm{Br}_{3} \mathrm{Ga}(\mathrm{TMP})$ and $\mathrm{I}_{3} \mathrm{Ga}(\mathrm{TMP})$ dissolved in mixed solvents of ethyl acetate and dichloromethane in air. The reactions were quantitative at $20 \mathrm{mg}$ in $10 \mathrm{~mL}$ mixed solvents. $\mathrm{Cl}_{3} \mathrm{Ga}\left(\mathrm{O}=\mathrm{P}(\mathrm{TMOP})_{3}\right)$ : Anal. Calc. for $\left(\mathrm{C}_{27} \mathrm{H}_{33} \mathrm{Cl}_{3} \mathrm{GaO}_{10} \mathrm{P}\right)$ : C, $44.75 \%, \mathrm{H}, 4.59 \%$. Found: $\mathrm{C}$, $44.62 \%, \mathrm{H}, 4.58 \%$. $\mathrm{Br} 33 \mathrm{Ga}\left(\mathrm{O}=\mathrm{P}(\mathrm{TMOP})_{3}\right):$ Anal. Calc. for $\left(\mathrm{C}_{27} \mathrm{H}_{33} \mathrm{Br}_{3} \mathrm{GaO}_{10} \mathrm{P}\right): \mathrm{C}, 37.80 \%, \mathrm{H}$, $3.88 \%$. Found: $\mathrm{C}, 37.74 \%, \mathrm{H}, 3.87 \%$. $\mathrm{I}_{3} \mathrm{Ga}\left(\mathrm{O}=\mathrm{P}(\mathrm{TMOP})_{3}\right)$ : Anal. Calc. for $\left(\mathrm{C}_{27} \mathrm{H}_{33} \mathrm{I}_{3} \mathrm{GaO}_{10} \mathrm{P}\right)$ : C, 32.46\%, H, 3.33\%. Found: C, 32.39\%, H, 3.34\%.

\subsection{Crystal Structure Determination}

Suitable crystals were mounted on glass fibers using mineral oil and data were collected using graphite-monochromated Mo $\mathrm{K}_{\alpha}$ irradiation $(0.71073 \AA)$ on a Bruker PLAT- 
FORM/SMART 1000 CCD diffractometer (Bruker, Bremen, Germany). The structure was solved by direct methods using SHELXL-2017 [17] and refined using full-matrix leastsquares on $F^{2}$ (SHELXL-2017) [17]. All the non-hydrogen atoms in the structure were refined with anisotropic displacement parameters. Selected crystal data and structure refinement details for all determined complexes are included in Table 1 (see Supplementary Materials).

Table 1. Crystal data and structure refinement details for complexes 1-3.

\begin{tabular}{|c|c|c|c|}
\hline Empirical Formula & $\mathrm{C}_{27} \mathrm{H}_{33} \mathrm{Cl}_{3} \mathrm{GaO}_{10} \mathrm{P}(1)$ & $\mathrm{C}_{27} \mathrm{H}_{33} \mathrm{Br}_{3} \mathrm{GaO}_{10} \mathrm{P}(2)$ & $\mathrm{C}_{27} \mathrm{H}_{33} \mathrm{GaI}_{3} \mathrm{O}_{10} \mathrm{P}(3)$ \\
\hline Formula weight & 724.57 & 857.95 & 998.92 \\
\hline Crystal system & Triclinic & Triclinic & Triclinic \\
\hline Crystal Dimensions & $0.38 \times 0.32 \times 0.24 \mathrm{~mm}$ & $0.36 \times 0.25 \times 0.15 \mathrm{~mm}$ & $0.36 \times 0.28 \times 0.10 \mathrm{~mm}$ \\
\hline Space group & Pī(No.2) & P $\overline{1}($ No. 2$)$ & P $\overline{1}($ No.2) \\
\hline \multicolumn{4}{|l|}{ Unit cell parameters } \\
\hline$a(\AA)$ & $11.0002(10)$ & $11.0820(11)$ & $11.2385(6)$ \\
\hline$b(\AA)$ & $12.1039(11)$ & $12.7203(14)$ & $12.6376(7)$ \\
\hline$c(\AA)$ & $14.0488(13)$ & $13.8490(16)$ & $13.3734(6)$ \\
\hline$\alpha\left(^{\circ}\right)$ & 72.6161(11) & $71.6261(14)$ & $104.4313(6)$ \\
\hline$\beta\left(^{\circ}\right)$ & $65.1529(11)$ & $68.7071(13)$ & $101.9588(6)$ \\
\hline$\gamma\left({ }^{\circ}\right)$ & $70.7251(11)$ & $69.7549(14)$ & $102.5358(6)$ \\
\hline Volume $\left(\AA^{3}\right)$ & $1614.9(3)$ & $1666.0(3)$ & $1725.65(16)$ \\
\hline Z & 2 & 2 & 2 \\
\hline Calculated density $\left(\mathrm{g} \mathrm{cm}^{-3}\right)$ & 1.490 & 1.710 & 1.922 \\
\hline Temperature, $\mathrm{K}$ & $173.2(1)$ & $173.2(1)$ & $173.2(1)$ \\
\hline$\mu(\mathrm{MoK} \alpha),\left(\mathrm{mm}^{-1}\right)$ & 1.201 & 4.522 & 3.576 \\
\hline$\theta$ range for data collection $\left(^{\circ}\right)$ & 0.3 to 27.49 & 0.3 to 26.61 & 0.3 to 27.48 \\
\hline Total data collected & 14,087 & 13,675 & 15,248 \\
\hline \multirow[t]{3}{*}{ Index ranges } & $-14 \leq \mathrm{h} \leq 14$ & $-13 \leq h \leq 13$ & $-14 \leq \mathrm{h} \leq 14$ \\
\hline & $-15 \leq \mathrm{k} \leq 15$ & $-16 \leq \mathrm{k} \leq 16$ & $-16 \leq \mathrm{k} \leq 16$ \\
\hline & $-18 \leq 1 \leq 18$ & $-17 \leq 1 \leq 17$ & $-17 \leq 1 \leq 17$ \\
\hline Independent reflections & $7290\left(\mathrm{R}_{\mathrm{int}}=0.0207\right)$ & $6946\left(\mathrm{R}_{\mathrm{int}}=0.0205\right)$ & $7842\left(\mathrm{R}_{\text {int }}=0.0126\right)$ \\
\hline Observed reflections & 5695 & 5475 & 7029 \\
\hline Data/restraints/parameters & $7290 / 0 / 379$ & $6946 / 10 / 400$ & $7842 / 0 / 379$ \\
\hline Goodness-of-fit on $F^{2}$ & 1.060 & 1.042 & 1.025 \\
\hline \multicolumn{4}{|l|}{ Final $R$ indices } \\
\hline$\left[F_{0}^{2} \geq 2 \sigma\left(F_{0}\right)\right]$ & $R_{1}=0.0502$ & $R_{1}=0.0346$ & $R_{1}=0.0274$ \\
\hline$w R_{2}\left[F_{0}^{2} \geq-3 \sigma\left(F_{0}^{2}\right)\right]$ & $w R_{2}=0.1336$ & $w R_{2}=0.0913$ & $w R_{2}=0.0754$ \\
\hline Large difference peak and hole & -1.388 and $1.546 \mathrm{e} / \AA^{3}$ & -0.947 and $0.674 \mathrm{e} / \AA^{3}$ & -0.829 and $1.495 \mathrm{e} / \AA^{3}$ \\
\hline
\end{tabular}

\section{Results and Discussion}

As we synthesized the donor-acceptor gallium(III) halide phosphine complexes, the used anhydrous gallium(III) halide precursors were very moisture sensitive. When we compared the gallium(III)-phosphine halide complexes in the solid state with the gallium(III) halides, we found the donor-acceptor adducts were much more stable than the metal halides. In addition, the gallium(III)-phosphine complexes dissolved in solution became oxygen sensitive and the coordinated phosphine ligand (Scheme 1) is easily oxidated to form gallium(III)-phosphine oxide complexes. The three new oxide compounds of $\left[\mathrm{GaX}_{3}\left(\mathrm{O}=\mathrm{P}(\mathrm{TMOP})_{3}\right]\right.$ were prepared through oxidation of three TMP solid complexes of $\mathrm{Cl}_{3} \mathrm{Ga}$ (TMP), $\mathrm{Br}_{3} \mathrm{Ga}$ (TMP) and $\mathrm{I}_{3} \mathrm{Ga}$ (TMP) dissolved in mixed solvents of ethyl acetate and dichloromethane in air. All three reactions were quantitative on a $20 \mathrm{mg}$ scale in $10 \mathrm{~mL}$ 1:1 mixed solvent for 2-3 days exposed in air. All three synthesized solid adducts were characterized by elemental analysis (EA) (see experimental section for data). 
<smiles></smiles>

Scheme 1. Methoxyl group substituted $(\mathrm{TMOP})_{3} \mathrm{P}=\mathrm{O}$ ligands and its bonding with gallium(III) complexes

Complexes 1, 2 and 3 were crystalized from their gallium(III)-phosphine oxide complex solutions. Their structures, solved by X-ray diffraction, are shown in Figures 1-3; see the figure captions for selected bond distances and angles. For all three halides, the gallium(III) metal is located at a site of tetrahedral geometry with three coordinated halides $\left(\mathrm{Cl}^{-}, \mathrm{Br}^{-}\right.$or $\left.\mathrm{I}^{-}\right)$and one oxygen (phosphine oxide). The $\mathrm{O}-\mathrm{Ga}$ bond distances increase slightly from $\mathrm{Cl}^{-}$to I- ${ }^{-}$, as do the Ga-O-P bond angles, increasing from 158.66(17) for $\mathrm{Cl}^{-}$, 159.91(16) for $\mathrm{Br}^{-}$and 163.88(15) for the $\mathrm{I}^{-}$.

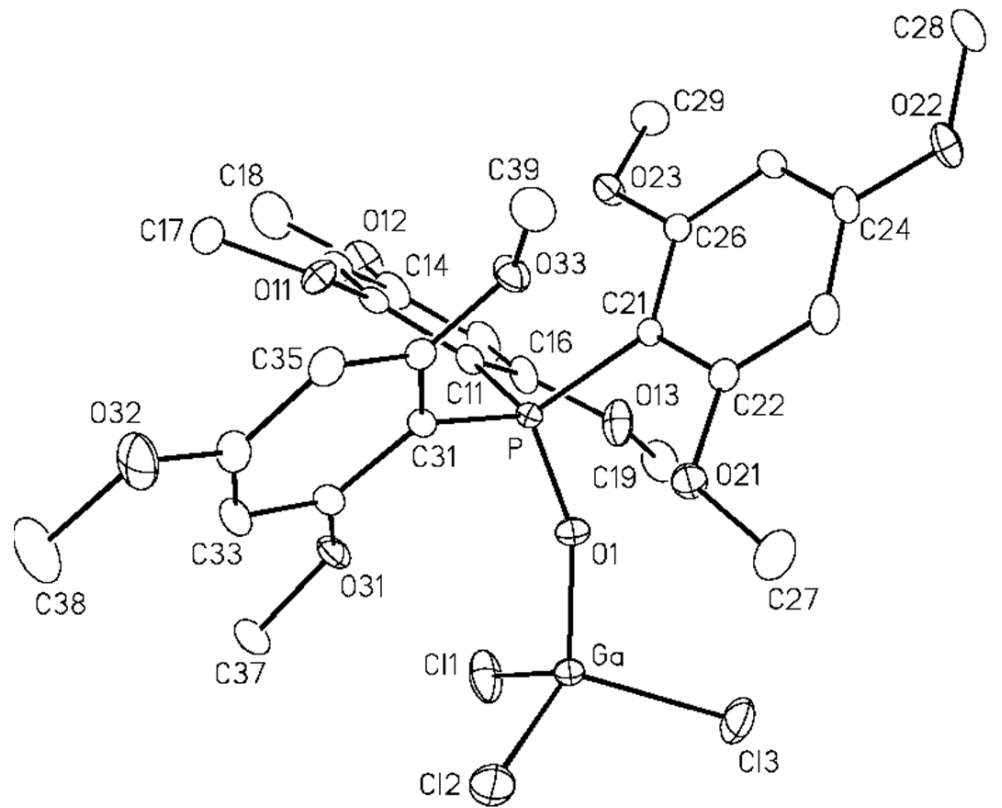

Figure 1. Perspective view of the [\{tris(2,4,6-trimethoxyphenyl)phosphine oxide $\left.\} \mathrm{GaCl}_{3}\right]$ (1) molecule, showing the atom labeling scheme.

Bond distances $(\AA)$ and bond angles $\left(^{\circ}\right)$ : $\mathrm{Ga}-\mathrm{Cl}(1)=2.1812(12), \mathrm{Ga}-\mathrm{Cl}(2)=2.1582(13)$, $\mathrm{Ga}-\mathrm{Cl}(3)=2.1611(11), \mathrm{Ga}-\mathrm{O}(1)=1.787(2), \mathrm{P}-\mathrm{O}(1)=1.522(2), \mathrm{P}-\mathrm{C}(11)=1.790(3)$, $\mathrm{P}-\mathrm{C}(21)=1.797(3), \mathrm{P}-\mathrm{C}(31)=1.796(3) ; \mathrm{Cl}(1)-\mathrm{Ga}-\mathrm{Cl}(2)=111.80(6), \mathrm{Cl}(2)-\mathrm{Ga}-\mathrm{Cl}(3)=110.23(5)$, $\mathrm{Cl}(3)-\mathrm{Ga}-\mathrm{Cl}(1)=108.63(6), \mathrm{Cl}(1)-\mathrm{Ga}-\mathrm{O}(1)=109.45(10), \mathrm{Ga}-\mathrm{O}(1)-\mathrm{P}=158.66(17)$.

Bond distances $(\AA)$ and bond angles $\left({ }^{\circ}\right): \mathrm{Ga}(1 \mathrm{~A})-\mathrm{Br}(1 \mathrm{~A})=2.3101(8), \mathrm{Ga}(1 \mathrm{~A})-\mathrm{Br}(2 \mathrm{~A})$ $=2.3117(7), \mathrm{Ga}(1 \mathrm{~A})-\mathrm{Br}(3 \mathrm{~A})=2.3040(10), \mathrm{Ga}(1 \mathrm{~A})-\mathrm{O}(1)=1.813(2), \mathrm{P}-\mathrm{O}(1)=1.514(2), \mathrm{P}-\mathrm{C}(11)$ $=1.795(3), \mathrm{P}-\mathrm{C}(21)=1.795(3), \mathrm{P}-\mathrm{C}(31)=1.793(3) ; \mathrm{Br}(1 \mathrm{~A})-\mathrm{Ga}(1 \mathrm{~A})-\mathrm{Br}(2 \mathrm{~A})=109.06(3)$, 
$\mathrm{Br}(2 \mathrm{~A})-\mathrm{Ga}(1 \mathrm{~A})-\mathrm{Br}(3 \mathrm{~A})=112.90(3), \mathrm{Br}(3 \mathrm{~A})-\mathrm{Ga}(1 \mathrm{~A})-\mathrm{Br}(1 \mathrm{~A})=108.99(4), \mathrm{Br}(1 \mathrm{~A})-\mathrm{Ga}(1 \mathrm{~A})-\mathrm{O}(1)$ $=108.28(8), \mathrm{Ga}(1 \mathrm{~A})-\mathrm{O}(1)-\mathrm{P}=159.91(16)$.

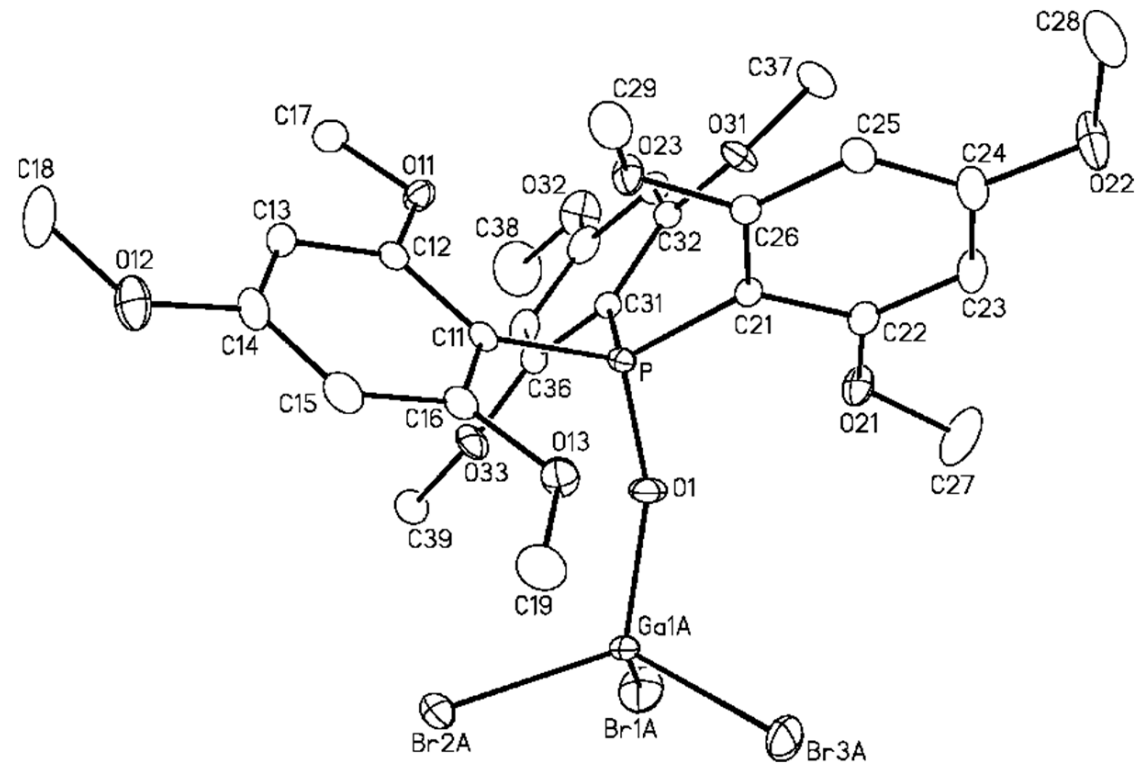

Figure 2. Perspective view of the [\{tris(2,4,6-trimethoxyphenyl)phosphine oxide $\left.\} \mathrm{GaBr}_{3}\right]$ (2) molecule, showing the atom labeling scheme. The $90 \%$ conformer of $\left\{\mathrm{Ga}_{1} \mathrm{~A}\left(\mathrm{Br}_{1} \mathrm{ABr}_{2} \mathrm{ABr} 3 \mathrm{~A}\right)\right\}$ present in the crystal structure is shown here; see Figure 4 for the $10 \%$ conformer.

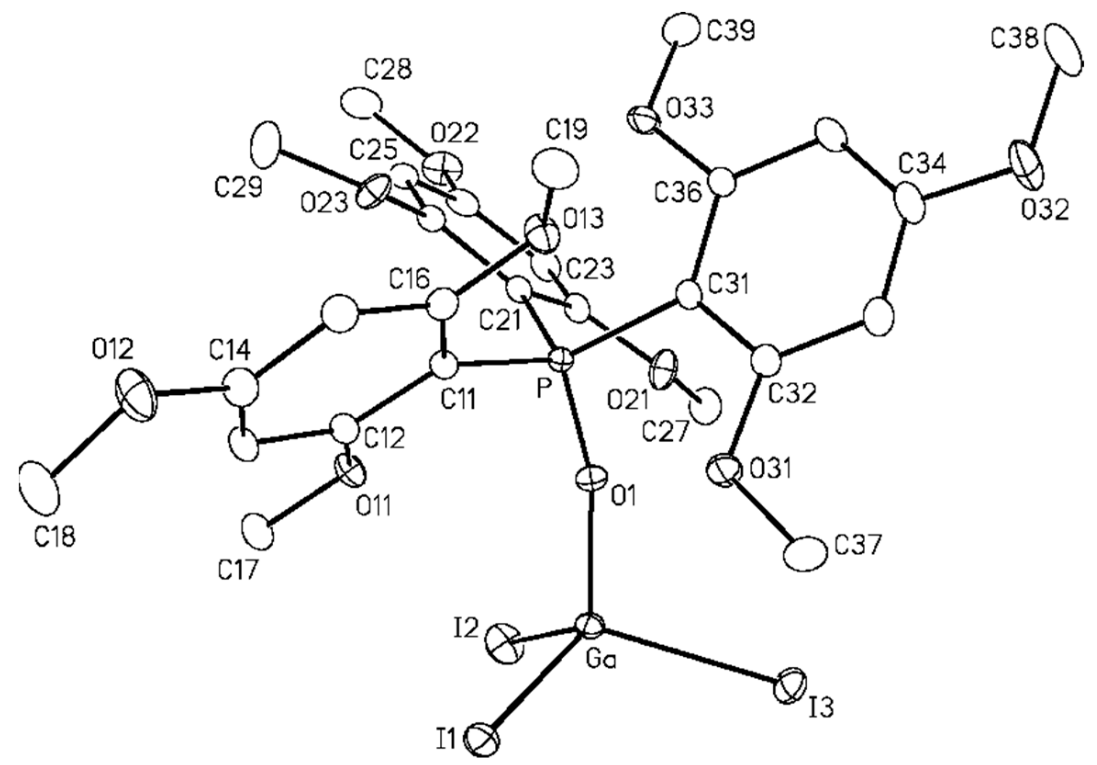

Figure 3. Perspective view of the [\{tris(2,4,6-trimethoxyphenyl)phosphine oxide $\left.\left.\}_{G_{a}}\right]_{3}\right]$ (3) molecule, showing the atom labeling scheme.

Bond distances $(\AA)$ and bond angles $\left(^{\circ}\right)$ : Ga-I(1) = 2.5319(4), Ga-I(2) = 2.5190(4), Ga-I(3) $=2.5260(4), \mathrm{Ga}-\mathrm{O}(1)=1.810(2), \mathrm{P}-\mathrm{O}(1)=1.515(2), \mathrm{P}-\mathrm{C}(11)=1.802(3), \mathrm{P}-\mathrm{C}(21)=1.799(3)$, $\mathrm{P}-\mathrm{C}(31)=1.794(3) ; \mathrm{I}(1)-\mathrm{Ga}-\mathrm{I}(2)=112.303(14), \mathrm{I}(2)-\mathrm{Ga}-\mathrm{I}(3)=109.511(14), \mathrm{I}(3)-\mathrm{Ga}-\mathrm{I}(1)$ $=111.272(14), \mathrm{I}(1)-\mathrm{Ga}-\mathrm{O}(1)=108.93(7), \mathrm{Ga}-\mathrm{O}(1)-\mathrm{P}=163.88(15)$.

The crystal structure for 2 was refined with two conformers of the $\mathrm{GaBr}_{3}$ unit with a major $(90 \%$, labelled A) and minor $(10 \%$, labelled B) conformers, as shown in Figure $4 \mathrm{a}$. This disorder is not present for $\mathbf{1}$ and $\mathbf{3}$, which exhibit nearly identical molecular. 


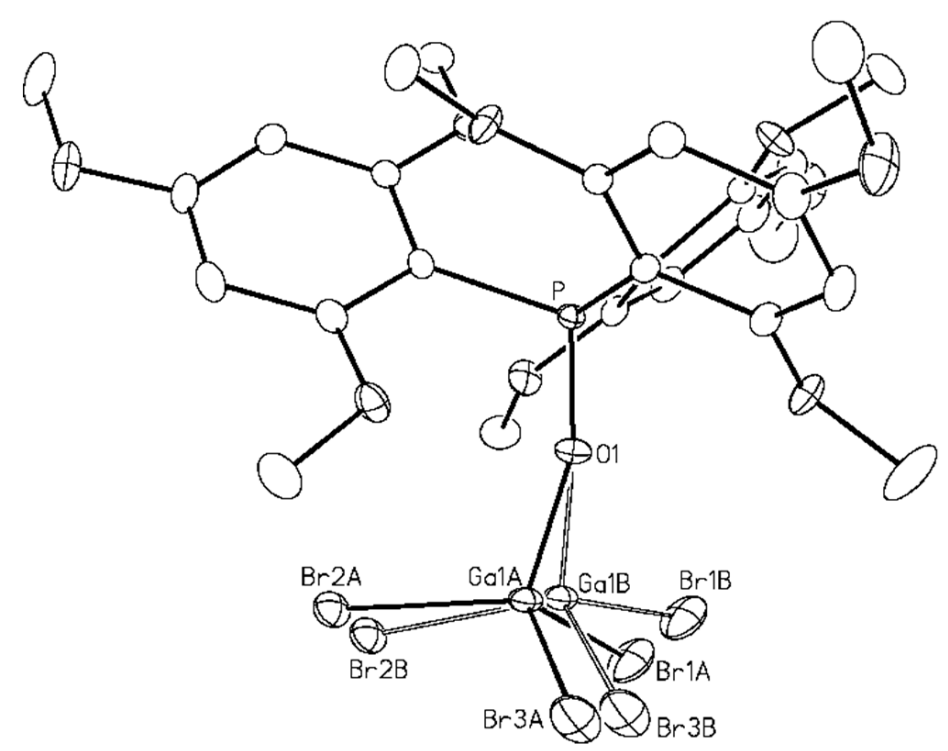

(a)

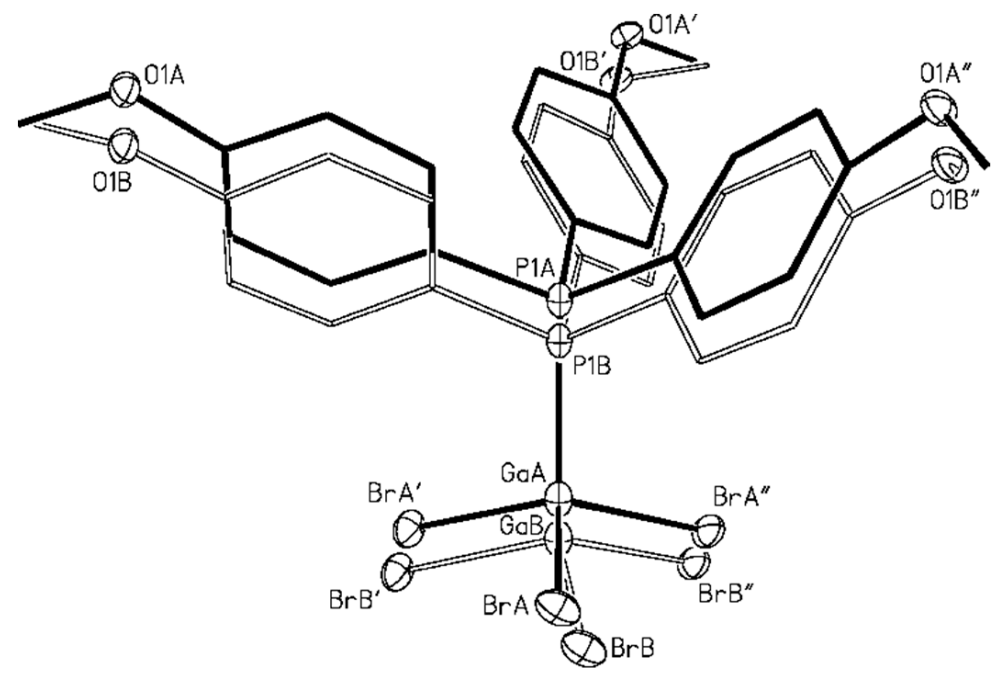

(b)

Figure 4. (a) View of complex 2 showing the relative positions of both the major and minor orientations of the disordered $\mathrm{GaBr}_{3}$ group. (b) Representation of the disordered mode of complex 2. Carbon atom thermal ellipsoids are not shown. Bonds within the major $(90 \%)$ conformer (containing the atoms $\mathrm{Br}(\mathrm{A}), \mathrm{Ga}(\mathrm{A}), \mathrm{P}(1 \mathrm{~A})$, and $\mathrm{O}(1 \mathrm{~A})$ ) are shown as solid lines; within the minor $(10 \%)$ conformer (containing the atoms $\mathrm{Br}(\mathrm{B}), \mathrm{Ga}(\mathrm{B}), \mathrm{P}(\mathrm{B})$ ), and $\mathrm{O}(1 \mathrm{~B})$ ), bonds are represented by hollow lines. The conformers are separated by a translation of approximately $0.5 \AA$ along the crystal $\mathrm{z}$ axis.

Since the three structures are isostructural, an overlay is shown in Figure 5 to illustrate the similarity of these structures. The chloride and iodide structures overlay well (Figure 5a), but the aryl ligands of the bromide do not match as well (Figure 5b).

According to a definition by Jeffrey, a significant hydrogen bond is categorized by donor-acceptor distances of less than $3.5 \AA$, while those in the range of $3.2 \sim 4.0 \AA$ are considered "weak, electrostatic" hydrogen bonding with energies less than $16.74 \mathrm{~kJ} / \mathrm{mol}$ [18]. A hydrogen with donor-acceptor distances of 3.122 3.521 $\AA$ was determined in our previous crystal structure report, which can be considered a weak electrostatic hydrogen bond [9]. Thus, we considered whether 1, 2 or $\mathbf{3}$ have a similar type of hydrogen bond interaction. The hydrogen bond distances within or near $3.5 \AA$ are listed in Table 2 and a diagram to illustrate the intramolecular hydrogen bonding is shown in Figure 6; these 
data clearly indicate that weak electrostatic donor-acceptor hydrogen bonds are present in these complexes.

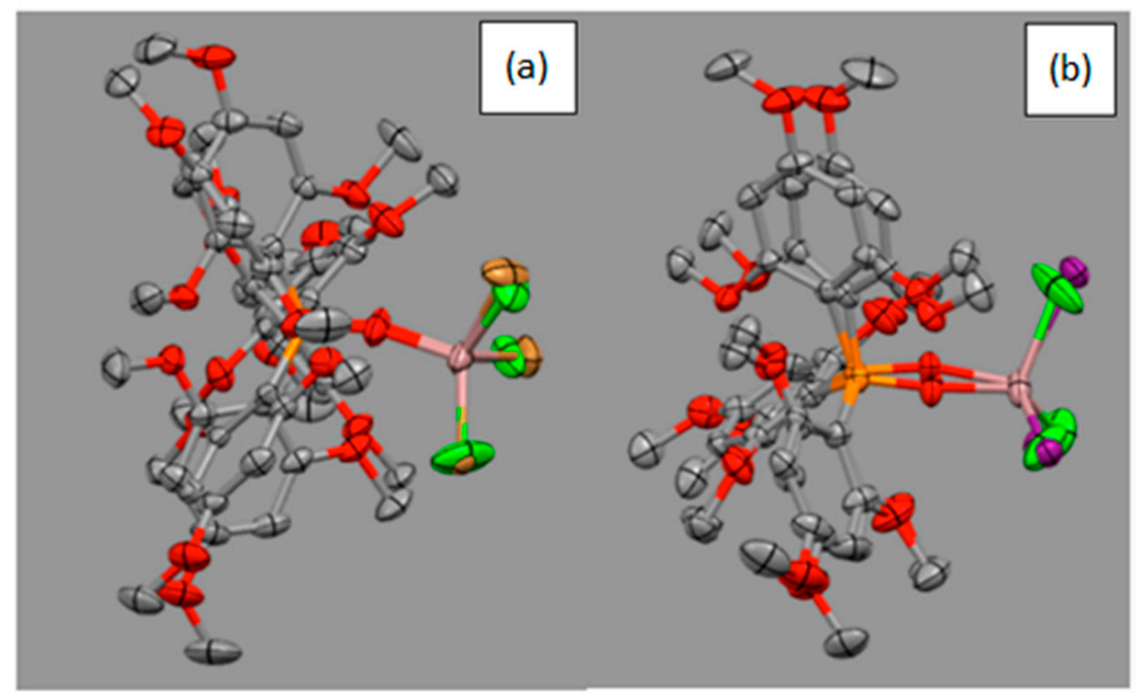

Figure 5. Overlay of two molecular structures. (a): the $\mathrm{Cl} / \mathrm{I}$ and (b): the $\mathrm{Cl} / \mathrm{Br}$ adducts structures. The major $(90 \%)$ and minor (10\%) conformers were also present in a $\mathrm{GaBr}_{3}$-phosphine complex in our previous work [10], but not in crystal structures of $\mathrm{Cl}^{-}$and $\mathrm{I}^{-}$anion also (Figure $4 \mathrm{~b}$ ).

Table 2. Hydrogen bonding in 1, 2 and $3(\AA)$.

\begin{tabular}{cc}
\hline D-H-A & H-A \\
\hline $\mathrm{O}(13)-\mathrm{C}(19)-\mathrm{H}-\mathrm{Cl}(1)$ & $3.074(3)$ \\
\hline $\mathrm{O}(31)-\mathrm{C}(37)-\mathrm{H}-\mathrm{Cl}(1)$ & $3.084(4)$ \\
\hline $\mathrm{O}(31)-\mathrm{C}(37)-\mathrm{H}-\mathrm{Cl}(2)$ & $2.964(3)$ \\
\hline $\mathrm{O}(33)-\mathrm{C}(39)-\mathrm{H}-\mathrm{Br}(1 \mathrm{~A})$ & $3.155(4)$ \\
\hline $\mathrm{O}(33)-\mathrm{C}(39)-\mathrm{H}-\mathrm{Br}(1 \mathrm{~B})$ & $3.056(3)$ \\
\hline $\mathrm{O}(13)-\mathrm{C}(19)-\mathrm{H}-\mathrm{Br}(2 \mathrm{~A})$ & $3.097(4)$ \\
\hline $\mathrm{O}(13)-\mathrm{C}(19)-\mathrm{H}-\mathrm{Br}(2 \mathrm{~B})$ & $3.485(4)$ \\
\hline $\mathrm{O}(13)-\mathrm{C}(19)-\mathrm{H}-\mathrm{Br}(3 \mathrm{~A})$ & $3.517(4)$ \\
\hline $\mathrm{O}(11)-\mathrm{C}(17)-\mathrm{H}-\mathrm{I}(1)$ & $3.497(4)$ \\
\hline $\mathrm{O}(21)-\mathrm{C}(27)-\mathrm{H}-\mathrm{I}(2)$ & $3.473(4)$ \\
\hline $\mathrm{O}(31)-\mathrm{C}(37)-\mathrm{H}-\mathrm{I}(3)$ & $3.366(3)$ \\
\hline
\end{tabular}
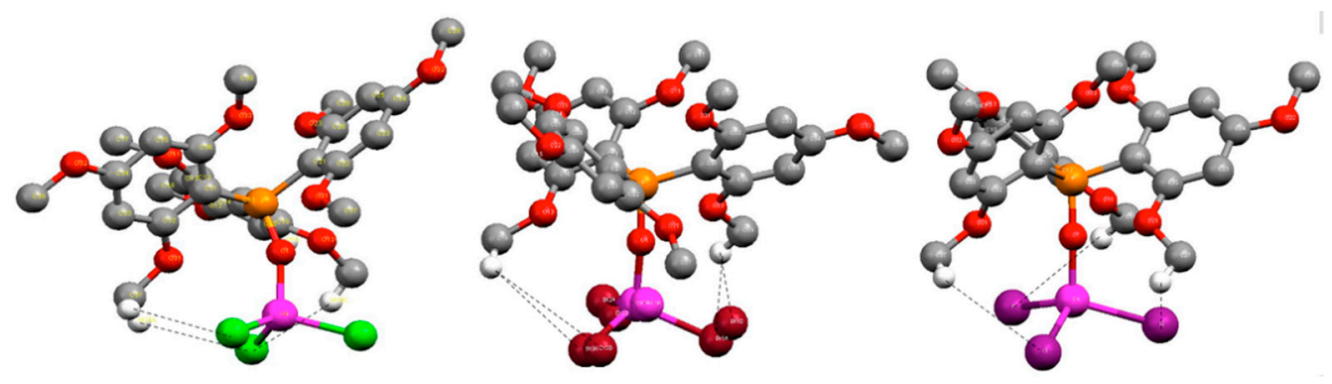

Figure 6. Intramolecular hydrogen bonding of three structures as listed in Table 2.

There are a some crystal structures $\left[\mathrm{Cl}_{3} \mathrm{Ga}\left(\mathrm{O}=\mathrm{PPh}_{3}\right)\right](\mathrm{O}-\mathrm{Ga}=1.818(10) \AA)[11]$, $\left[\left(c-\mathrm{C}_{6} \mathrm{H}_{11}\right)_{7} \mathrm{Si}_{7} \mathrm{O}_{12} \mathrm{Ga}\left(\mathrm{O}=\mathrm{PPh}_{3}\right)\right](\mathrm{O}-\mathrm{Ga}=1.866(2) \AA)$ and [ ${ }^{\mathrm{t}}(\mathrm{Bu})_{2} \mathrm{Ga}\left(o-\mathrm{C}_{6} \mathrm{H}_{4} \mathrm{NMe}_{2}\right)\left(\mathrm{O}=\mathrm{PPh}_{3}\right)$ 
$(\mathrm{O}-\mathrm{Ga}=2.091(3) \AA$ ) [13], which contain O-Ga donating bond between an organic oxygen ligand and gallium metal without any intramolecular hydrogen bonding. The bond length of structure $1(\mathrm{O}-\mathrm{Ga}=1.787(2) \AA)$, containing similar gallium chloride, is much shorter than these three structures, indicating that intramolecular hydrogen bonding provides additional stability to enhance the bond interactions between gallium metal centers and oxygen donor atoms.

As a typical phosphine is slowly oxidized in air through a photolysis radical mechanism, a radical cation forms and reacts with dioxygen to generate a peroxy radical that ultimately leads to 2 moles of phosphine oxide [19]. When phosphine gallium(III) halide adducts are present in inert gas, the oxidation process never occurs. However, in air, the oxidation reaction happens quickly (Scheme 2). There are few organometallic gallium(III) radical complexes reported in the literature [20,21], where organic radical ligands coordinated with gallium complexes were formed. In our case, they do not result in the formation of organometallic conjugated gallium complexes and, as we learned from the reported literature, $p$-block halides $\left(\mathrm{GaX}_{3}\right)$ do not promote or catalyze the air oxidation of $\mathrm{R}_{3} \mathrm{P}$ to $\mathrm{R}_{3} \mathrm{PO}$ [22]. Thus, the oxidation of the phosphine ligand occurs naturally in solution due to oxygen in the air, as has been reported in the literature [23].

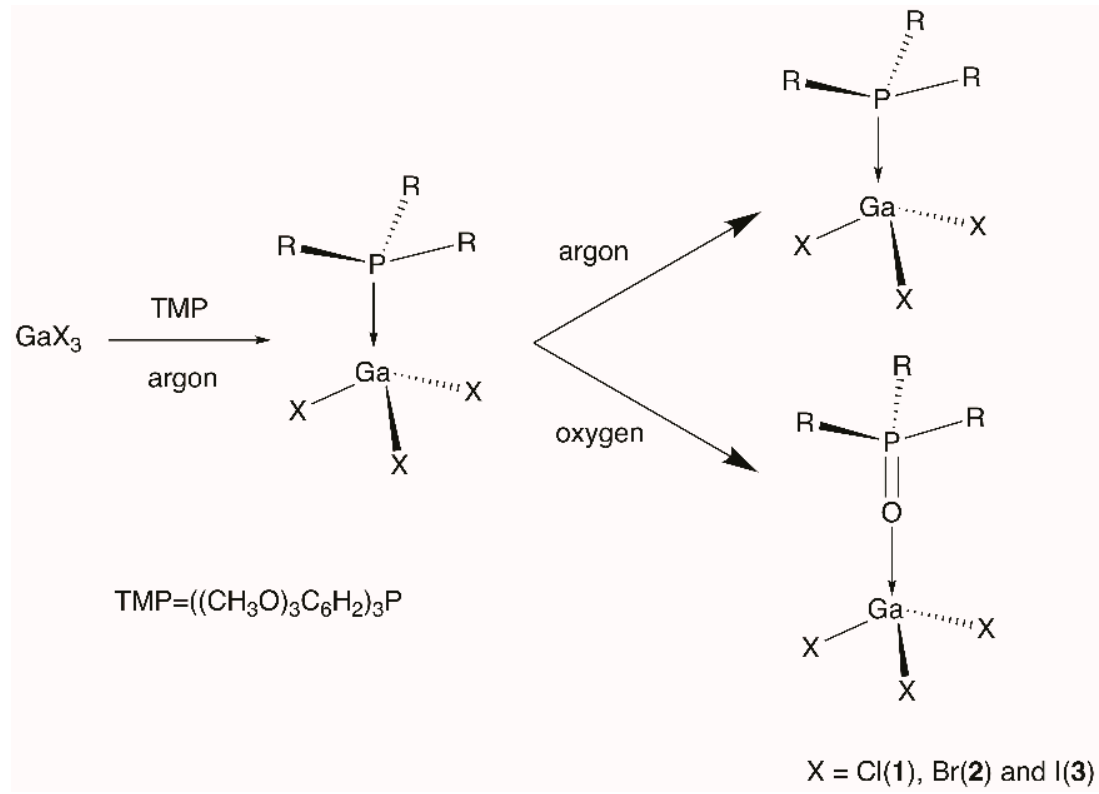

Scheme 2. Reactivity of 1:1 adducts of gallium(III) halides with phosphine ligands in different gas atmospheres.

Three gallium halide structures were determined in this work. As discussed in the introduction, these bulky ligands are difficult to crystallize due to low solubility. The CCDC database lists only 12 crystal structures of phosphine oxide with gallium(III) [22,24-26]; however, the ligands used in these are not as bulky as the TMOP used in this work.

\section{Conclusions}

The synthesis of donor-acceptor adducts of bulky ligands with group 13 elements was reported, but crystal structures are rarely available due to the challenges of growing crystals of these complexes. In this paper, three new gallium(III) halide oxygen donor-acceptor adducts with bulky phosphine oxide ligands were generated through the oxidation of the phosphine bonding ligands to phosphine oxide in solution. Three crystalline complexes were grown from the mixed solvents and their crystal structures were solved by $\mathrm{X}$-ray diffraction. A tetrahedral geometry with three coordinated halides $\left(\mathrm{Cl}^{-}, \mathrm{Br}^{-}\right.$or $\left.\mathrm{I}^{-}\right)$and one oxygen (phosphine oxide) are present in these three structures. In addition, weakly formed hydrogen bonds are present within the molecular structures between halides and 
the functional group of the ligand, which provide an additional interaction contributing to the stability of the donor-acceptor adducts.

Supplementary Materials: CCDC 1995186-1995188 contains the supplementary crystallographic data for this paper. These data can be obtained free of charge via www.ccdc.cam.ac.uk/data_request/cif, or by emailing data_request@ccdc.cam.ac.uk, or by contacting The Cambridge Crystallographic Data Centre, 12 Union Road, Cambridge CB2 1EZ, U.K.; Fax: +44-1223-336033.

Author Contributions: M.S., S.G., J.Z., R.M., M.F. and G.M. planned the experimental synthesis and characterization approach. R.M. and M.F. solved the crystal structures and the other authors collected the data and prepared all figures and tables as well as writing the manuscript. All authors have read and agreed to the published version of the manuscript.

Funding: This research received no external funding.

Institutional Review Board Statement: Not applicable.

Informed Consent Statement: Not applicable.

Data Availability Statement: Not applicable.

Acknowledgments: This work was performed at the Institute of Carbon Materials Science of Shanxi Datong University in Datong, and supported by Foundation items: National Natural Science Foundation of China (52071192), Shanxi 1331 project foundation for graphene industrialization application technology of collaborative innovation center, Shanxi new carbon functional materials engineering research center, Shanxi Science and Technology Major Project (20181102003), Shanxi Science and Technology Achievements Transformation Guide Project (201804D131041), Science and Technology Innovation Project of Universities in Shanxi Province (2019L0773, 2019L0771). The authors would like to thank the University of Alberta for support to maintain the X-ray Crystallography and Analytical and Instrumentation laboratories at the Department of Chemistry, which were essential for this work. The authors thank Guy Bernard for his helpful comments.

Conflicts of Interest: The authors declare no competing interest.

\section{References}

1. Jonas, V.; Frenking, G. Studies on the boron-nitrogen bond length of the classical donor-acceptor complex H3N-BF3. J. Chem. Soc. Chem. Commun. 1994, 1489-1490. [CrossRef]

2. Timoshkin, A.Y.; Suvorov, A.V.; Bettinger, H.F.; Schaefer, H.F. Role of the Terminal Atoms in the Donor-Acceptor Complexes MX3-D ( $\mathrm{M}=\mathrm{Al}, \mathrm{Ga}, \mathrm{In} ; \mathrm{X}=\mathrm{F}, \mathrm{Cl}, \mathrm{Br}, \mathrm{I}$; $\left.\mathrm{D}=\mathrm{YH}_{3}, \mathrm{YX}_{3}, \mathrm{X}^{-} ; \mathrm{Y}=\mathrm{N}, \mathrm{P}, \mathrm{As}\right)$. J. Am. Chem. Soc. 1999, 121, 5687-5699. [CrossRef]

3. Zhang, J.; Ge, S.; Zhao, J.; Ulhaq, I.; Ferguson, M.J.; Mcdonald, R.; Ma, G.; Ronald, C.G. Synthesis and Structures of Bis(iminophosphorano)methanide Chelate Complexes with Zinc and Group 13. Polyhedron 2019, 159, 167-175. [CrossRef]

4. Ge, S.; Zhao, J.; Ferguson, M.J.; Ma, G.; Cavell, R.G. Rare Carbon-Bridged Bimetallic Lanthanide (Nd or Sm) and Tl(I) Geminal Carbon Derivatives of a Bis(iminophosphorano)methanediide. Organometallics 2020, 39, 478-486. [CrossRef]

5. Ma, G.; Kritikos, M.; Maliarik, M.; Glaser, J. Modification of Binuclear PtTl Bonded Complexes by Attaching Bipyridine Ligands to the Thallium Site. Inorg. Chem. 2004, 43, 4328-4340. [CrossRef]

6. Ma, G.; Fischer, A.; Glaser, J. Synthesis and Structure of Monomeric and Platinum-Bonded (1,10-Phenanthroline)thallium Complexes. Eur. J. Inorg. Chem. 2002, 2002, 1307-1314. [CrossRef]

7. Carty, A.J. Coordination complexes of gallium(III) and indium(III) halides. II. Far-infrared spectra of gallium(III) halide complexes with triarylphosphines. Can. J. Chem. 1967, 45, 3187-3192. [CrossRef]

8. Carty, A.J.; Hinsperger, T.; Boorman, P.M. Coordination complexes of gallium(III) and indium(III) halides. V. Trialkyl and mixed alkyl $\backslash \mathbf{u} 2013$ aryl phosphine complexes of indium(III) chloride, bromide, and iodide. Can. J. Chem. 1970, 48, 1959-1970. [CrossRef]

9. Chen, F.; Ma, G.; Bernard, G.M.; Cavell, R.G.; McDonald, R.; Ferguson, M.J.; Wasylishen, R.E. Solid-state 115In and 31P NMR studies of triarylphosphine indium trihalide adducts. J. Am. Chem. Soc. 2010, 132, 5479-5493. [CrossRef]

10. Chen, F.; Ma, G.; Bernard, G.M.; Wasylishen, R.E.; Ferguson, M.J. An investigation of 1:1 adducts of gallium trihalides with triarylphosphines by solid-state (69/71)Ga and 31P NMR spectroscopy. Chem.-Eur. J. 2013, 19, 2826-2838. [CrossRef]

11. Burford, N.; Royan, B.W.; Spence, R.E.v.H.; Cameron, T.S.; Linden, A.; Gogers, R.D. Linear co-ordinative bonding at oxygen: A spectroscopic and structural study of phosphine oxide-group 12 Lewis acid adducts. J. Chem. Soc. Dalton Trans. 1990, 21, 1521-1528. [CrossRef]

12. Feher, F.J.; Budzichowski, T.A.; Ziller, J.W. Synthesis and characterization of gallium-containing silsequioxanes. Inorg. Chem. 1997, 36, 4082-4086. [CrossRef] 
13. McMahon, C.N.; Bott, S.G.; Barron, A.R. Observation of an unusual amine oxidation reaction during the oxidation and hydrolysis of $\left[\left({ }^{\mathrm{t}} \mathrm{Bu}\right)_{2} \mathrm{Ga}\left(o-\mathrm{C}_{6} \mathrm{H}_{4} \mathrm{NMe}\right)\right]$ : Molecular structures of $\left[\left({ }^{\mathrm{t}} \mathrm{Bu}\right)_{2} \mathrm{Ga}\left(o-\mathrm{C}_{6} \mathrm{H}_{4} \mathrm{~N}(\mathrm{O}) \mathrm{Me}_{2}\right)\right]$ and $\left[\left({ }^{\mathrm{t}} \mathrm{Bu}\right)_{2} \mathrm{Ga}\left(o-\mathrm{C}_{6} \mathrm{H}_{4} \mathrm{NMe} \mathrm{NM}_{2}\right)\left(\mathrm{O}=\mathrm{PPh}_{3}\right)\right]$. Polyhedron 1997, 16, 3407-3413. [CrossRef]

14. Peppe, C.; Nobrega, J.A.; Hernandes, M.Z.; Longo, R.L.; Tuck, D.G. Preparation, crystal structure determination, and properties of adducts of halogenomethyl compounds of indium with group 16 donors. J. Organomet. Chem. 2001, 626, 68-75. [CrossRef]

15. Peppe, J.; Mello, M.d.A.; Wioppiold, T.A.; Lang, E.S. Synthesis of dihalogenidoindium(III) ions by halide transfer involving tellurium compounds in the presence of hard and soft ligands. J. Organomet. Chem. 2012, 718, 52-56. [CrossRef]

16. Weiss, J.; Prermeier, T.; Fischer, R.A. Reactions of elemental indium and indium(I) bromide with nickel-bromine bonds: Structure of $\left(\eta^{5}-\mathrm{C}_{5} \mathrm{H}_{4}\right)\left(\mathrm{Ph}_{3} \mathrm{P}\right) \mathrm{Ni}-\mathrm{InBr}_{2}\left(\mathrm{O}=\mathrm{PPh}_{3}\right)$. Inorg. Chem. 1996, 35, 71-75. [CrossRef]

17. Sheldrick, G.M. Crystal structure refinement with SHELXL. Acta Crystallogr. Sect. C 2015, C71, 3-8. [CrossRef]

18. Minch Michael, J. An Introduction to Hydrogen Bonding (Jeffrey, George A.). J. Chem. Educ. 1999, 76, 759. [CrossRef]

19. Stewart, B.; Harriman, A.; Higham, L.J. Predicting the Air Stability of Phosphines. Organometallics 2011, 30, 5338-5343. [CrossRef]

20. Sokolov, V.G.; Koptseva, T.S.; Moskalev, M.V.; Bazyakina, N.L.; Fedushkin, I.L. Gallium Hydrides with a Radical-Anionic Ligand. Inorg. Chem. 2017, 56, 13401-13410. [CrossRef]

21. Kimura, S.; Bill, E.; Bothe, E.; Weyhermuller, T.; Weighardt, K. Phenylthiyl Radical Complexes of Gallium(III), Iron(III), and Cobalt(III) and Comparison with. J. Am. Chem. Soc. 2001, 123, 6025-6039. [CrossRef] [PubMed]

22. Cheng, F.; Codgbrook, H.L.; Hector, A.L.; Levason, W.; Reid, G.; Webster, M.; Zhang, W. Gallium(III) halide complexes with phosphines, arsines and phosphine oxides-A comparative study. Polyhedron 2007, 26, 4147-4155. [CrossRef]

23. Cobb, J.E.; Cribbs, C.M.; Henke, B.R.; Uehling, D.E.; Hernan, A.G.; Matin, C.; Rayner, C.M. Triphenylphosphine. In Encyclopedia of Regents for Organic Synthesis; Raquette, L., Ed.; J. Wiley \& Sons: New York, NY, USA, 2004; ISBN 0471936235. [CrossRef]

24. Bresien, J.; Faust, K.; Schulz, A.; Villinger, A. Low-Temperature Isolation of the Bicyclic Phosphinophosphonium Salt [Mes*2P4Cl][GaCl4]. Angew. Chem. Int. Ed. 2015, 54, 6926-6930. [CrossRef] [PubMed]

25. Samanamu, C.R.; Olmstead, M.M.; Montchamp, J.L.; Richards, A.F. Convenient Synthesis of Aluminum and Gallium Phosphonate Cages. Inorg. Chem. 2008, 47, 3879-3887. [CrossRef] [PubMed]

26. Liu, L.L.; Stephan, D.W. An imine-gallium Lewis pair stabilized oxophosphinidene via an unexpected phosphirene rearrangement. Chem. Commun. 2018, 54, 1041-1044. [CrossRef] 